$\mathbf{2 7}(5), 667-679$

\title{
A Decision-support System for Care Plan in Long-term Care Insurance
}

\author{
Eun-Jeong $\operatorname{Han}^{a} \cdot$ Jung-Suk Lee ${ }^{a} \cdot{\text { Dong-Geon } \operatorname{Kim}^{b}}^{b}$ Jinhee Kwon ${ }^{a, 1}$ \\ ${ }^{a}$ Health Insurance Policy Research Institute, National Health Insurance Services \\ ${ }^{b}$ Department of data \& Information Science, Dongduk Women's University
}

(Received May 9, 2014; Revised July 10, 2014; Accepted September 15, 2014)

\begin{abstract}
National Health Insurance Service(NHIS) provide care-plans for beneficiaries in the long-term care insurance(LTCI) systems that help them use LTC services appropriately. The care-plan includes recommendations for the most adequate type of care (gold standard) for beneficiaries. This study develops a decision-support system to determine the appropriate type of care plan. To develop a model, we used a data set that welltrained assessors in the NHIS investigated as a gold standard for beneficiaries: nursing home care, home-visit care, home-visit bathing, home-visit nursing, or day and night care. The decision-support system was established through a decision-tree model, because it may be easy to explain the algorithm of a decision-support system to working groups and policy makers. Our results might be useful in evidence-based care planning in an LTCI system and contribute to the efficient use of LTC services.
\end{abstract}

Keywords: Long-term Care Insurance, care-plan, decision-tree model.

\section{1. 연구배경}

장기요양제도를 운영하는 $\mathrm{OECD}$ 국가들은 제도의 발전을 위하여 재정의 안정성, 재가서비스 활성화, 장기요양서비스 질 수준의 제고를 위한 다양한 전략들을 추진하고 있으며, 핵심 전략 가운데 하나로서 공적 영역에서의 케어매니지먼트(care management)를 강조하고 있다 (Jegal, 2011; OECD, 2011). 우리나라와 같이 장기요양제도를 사회보험방식으로 운영하는 경우에, 케어매니지먼트는 사회보험방식 의 표준화된 자원 할당 모드에서 수요자 중심의 개별화된 서비스 제공모드로의 효과적인 전환을 가능케 하는 핵심전달체계이다 (Seok, 2006). 특히 장기요양 인정자의 장기요양 욕구 충족과 자원 활용의 효율 성을 증가시키기 위하여, 장기요양서비스 이용자격에 대한 판정뿐만 아니라 인정자의 장기요양 욕구사 정 결과에 기반 한 과학적인 급여이용계획의 작성·제공(케어플랜)도 중요하게 여겨지고 있다. 이는 장 기요양이 필요하다고 인정된 자에게 단순히 이용자격 여부만을 결정하여 주는 것이 아니라 구체적으로 시설입소가 적합한지, 또는 가정에서 생활하면서 방문요양, 방문간호, 주야간보호 등 재가서비스를 이용 하는 것이 적합한지를 전문적으로 판단하여 수급자에게 필요한 서비스의 종류와 양을 정하여 권고하는 것을 의미한다.

\footnotetext{
${ }^{1}$ Corresponding author: Health Insurance Policy Research Institute National Health Insurance Services, 130, Mapo-daero, Mapo-gu, Seoul, 121-710, Korea. E-mail: kwonjh@nhis.or.kr/tmigkjh@naver.com
} 
일본과 호주의 경우에는 사회복지사, 간호사와 같은 전문가가 신청자의 건강상태 및 신청자와 가족의 옥 구 등을 파악하여 전문가의 종합적인 판단을 근거로 필요한 서비스 종류와 양을 정하여 서비스 이용을 지원하고 있고 (Matsuda과 Yamamoto, 2001; Commonwealth of Australia, 2006), 미국과 캐나다는 신청자에게 가장 적절한 이용계획을 제시해주기 위하여 통계적 기법을 바탕으로 자원 할당 알고리즘을 개발하여 이용하고 있다. 이것은 전문가에 의해 조사된 장기요양 욕구 평가 자료를 전산시스템에 입력 하면 알고리즘에 의해 신청자의 욕구에 맞는 서비스 종류가 도출되고 이를 바탕으로 케어플랜을 결정하 는 형태이다. 대표적인 알고리즘에는 Fries 등 (2002)이 개발한 미국 미시간 주의 MI-Choice와 Hirdes 등 (2008)이 개발한 캐나다 온타리오 주의 MAPLe이 있다. 이는 요양시설 입소 여부를 결정하는 알고 리즘으로 장기요양 필요도가 높은 사람이 주로 요양시설을 이용할 수 있게 하기 위한 알고리즘 개발에 대한 높은 요구로 인해 만들어졌다. 하지만 이는 고객의 장기요양서비스에 대한 옥구와는 상관없이 지 역사회의 재가서비스 자원을 할당하기 위한 장기요양서비스 결정 지원 알고리즘인 반면, MI-Choice는 대상자의 건강 및 기능 상태를 기반으로 대상자에게 적정한 서비스가 무엇인지를 권고하는 시스템으로, MDS-HC를 기본으로 개발된 알고리즘이다. 우리나라 노인장기요양보험에서는 수급자가 월 한도액 범 위 내에서 필요한 서비스를 비용-효과적으로 이용할 수 있도록 지원하고자 표준장기요양이용계획서(이 하 표준이용계획서)를 작성하여 제공하고 있다 (National Health, 2013). 그러나 표준이용계획서의 작 성자 특성에 따라 그 내용이나 범위에 편차가 있고 (Sunwoo 등, 2007), 표준이용계획서의 권고 급여 종 류와 실제 이용한 급여 종류의 일치도가 낮다 (Lee 등, 2008)는 문제가 제기되면서, 수급자의 기능 및 건강 상태에 근거하여 장기요양 급여 종류를 결정하는 객관적인 절차가 필요하였다.

이에 따라 Han 등 (2009)이 수급자의 건강 및 기능 상태를 고려하여 적정 급여를 제시하는 급여종류 알 고리즘(표준급여모형)을 개발한 바 있다. 하지만 이 연구는 다음과 같은 한계점을 갖는다. 첫째, 알고 리즘 개발에 사용된 표준이용계획서 자료가 전문적 지식과 노하우를 가진 훈련된 조사자에 의해 작성된 것이 아니고, 둘째, 수급자의 건강 및 기능 상태를 충분히 반영하여 작성하도록 안내하는 프로토콜이 반 영되지 않은 자료를 바탕으로 하였으며, 셋째, 시설급여 또는 재가급여로만 구분하는 알고리즘으로 방 문요양, 방문목욕, 방문간호, 주야간보호 등 표준이용계획서 작성에 요구되는 세부적인 재가급여 종류 별 권고모형을 개발하지 못하였다. 선행연구가 갖는 연구 자료의 한계점을 보완하고, 보다 구체적인 표 준급여모형을 필요로 하는 노인장기요양보험 실무 현장의 요구를 반영하여 알고리즘을 재개발할 필요가 있다.

이 연구는 수급자의 효과적인 서비스 이용을 지원하기 위하여 장기요양 필요도를 평가하는 인정조사도 구를 기본으로 시설급여와 재가급여, 그리고 재가급여의 세부 종류를 결정하는 과학적 알고리즘, 즉 표 준급여모형을 개발하는 데에 목적이 있다. 이 연구를 통하여 수급자의 건강 및 기능 상태에 적합한 최적 의 이용계획 작성을 지원하며 작성자 간 전문성에 따른 편차를 최소화시킬 수 있을 것이다.

\section{2. 연구방법}

\section{1. 연구대상 및 자료수집}

자료수집은 2009 년 4 월 1 일부터 5 월 31 일까지 2 개월간 전국 225 개 국민건강보험공단(이하 공단)의 장 기요양운영센터 중 협조를 얻지 못한 인천지역 5 개 운영센터를 제외한 220 개 장기요양운영센터를 통해 전국적으로 실시되었다. 220 개 장기요양운영센터에서 표준이용계획서를 가장 잘 작성하는 직원으로 인 정된 직원(파워어세서)을 선별하였다. 조사대상은 조사기간 내 장기요양인정에 대한 신규 및 갱신 신청 자 중 장기요양인정 $(1 \sim 3$ 등급)을 받은 자로 정하였다. 조사의 정확성을 높이기 위하여 220 명의 파워어 세서와 6 개 지역본부별 표준이용계획서 슈퍼바이저 18 명을 대상으로 2009 년 3 월 20 일부터 3 월 31 일까 
지 공단 본부에서 지역본부를 순회하면서 표준급여모형 개발의 목적, 조사내용 및 방법 등에 대한 교육 을 실시하였다. 자료수집에 대해서는 장기요양의 전문가적 입장에서 수급자의 건강과 기능 상태를 고려 했을 때의 적정한 서비스가 무엇인지에 대해서 작성하도록 하였고, 조사 시 다음 사항을 기본 원칙으로 하였다. 첫째, 수급자의 인구사회학적 특성을 배제한다. 즉, 연령, 거주지역, 비공식적 케어 등은 고려 하지 않고 작성하는 것을 전제로 하였다. 둘째, 수급자나 가족의 희망급여를 배제한다. 셋째, 노인장기 요양보험 급여 외의 지역사회 노인보건복지서비스 자원은 고려하지 않는다.

파워어세서로 선정된 220 명의 조사자의 특성에 대해 살펴보면, 여자가 183 명 $(83.2 \%)$, 남자가 37 명 $(16.8 \%)$ 이었고, 연령대는 30 대가 $48.6 \%$ 로 가장 많았으며, 평균연령은 35.5 세이었다. 표준이용계획서 작성 경력은 평균 10.3 개월이었다. 자격증 소지 현황을 보면, 간호사가 $57.7 \%$ 로 가장 많았고, 그 다음 으로는 사회복지사로 $48.6 \%$ 를 차지하였다.

조사기간 내 장기요양인정 신규 및 갱신 신청자는 9,452 명이었고, 이중 등급외자, 각하자, 사망자 210 명 과 독립변수에 사용될 항목에 결측이 있는 98 명을 제외한 9,144 명이 최종 분석대상자로 확정되었다.

\section{2. 분석변수}

2.2.1. 독립변수 표준급여모형의 독립변수는 노인장기요양보험 등급판정 시 수집되는 '장기요양인정 조사표'를 활용하였다. '장기요양인정조사표'는 노인장기요양보험 도입 당시에 개발된 것으로 신체기능, 수단적일상생활기능, 인지기능, 행동변화, 간호처치, 재활, 복지용구, 지원형태, 환경평가, 시력.청력상 태, 질병 및 증상 등 96 개 항목으로 구성되어 있다. 표준급여모형 개발을 위해서는 96 개 인정조사표 항목 중 신체기능 13 항목, 수단적일상생활기능 10 항목, 인지기능 10 항목, 행동변화 16 항목, 간호처치 10 개 항목, 재활 10 항목인 69 개 항목을 활용하였다. 신체기능, 수단적일상생활기능 항목은 타인의 도 움 필요 정도에 대해 3 점 척도(완전자립(1점), 부분도움(2점), 완전도움(3점))로 측정되고, 인지기능, 행동변화, 간호처치 항목은 증상의 유무, 처치의 유무(유(1점), 무(0점 $))$ 로 측정되며, 재활영역 항목은 운동장애 정도에 대해 3 점 척도(운동장애없음(1점), 불완전운동장애(2점), 완전운동장애(3점))로 측정 된다. 본 분석에서는 대상자의 중증도 측정 변수로 활용 (Lee 등, 2011; Hyun과 Lee, 2012; Lee 등, 2013 )되는 6 개 영역별 점수(영역별 문항의 점수 합)와 69 개 항목을 독립변수로 활용하였다. 자세한 변 수 설명은 Table 2.1 과 같다.

2.2.2. 종속변수 본 연구의 종속변수는 표준이용계획서 상에 권고된 장기요양급여의 종류이다. 장기 요양 서비스 종류는 크게 시설급여와 재가급여로 나뉘는데, 장기요양 인정자는 시설급여와 재가급여 중 한 가지만 이용할 수 있다. 인정자가 시설급여를 이용할 경우, 노인요양시설 등에 입소하여 장기요양 전 문가로부터 24 시간 케어를 받을 수 있고, 재가급여를 이용할 경우 가정에 머물면서 요양, 목욕, 간호, 주 야간보호 등의 방문서비스를 중복해서 받을 수 있다. 이에 본 연구의 종속변수는 전체 분석대상자를 대 상으로 하는 시설급여와 재가급여 권고여부(1(시설) vs 0 (재가))와 재가급여를 권고 받은 자를 대상으로 재가급여 4 가지 세부 종류를 결정하는 변수인 방문요양 권고여부( 1 vs 0$)$, 방문목욕 권고여부( 1 vs 0$)$, 방문간호 권고여부( 1 vs 0$)$, 주야간보호 권고여부( 1 vs 0$)$ 이다. 본 연구에서는 시설급여와 재가급여를 권고하는 단계를 표준급여모형 1 단계, 재가급여를 권고 받은 자를 대상으로 재가급여의 세부 종류를 권 고하는 단계를 표준급여모형 2 단계로 정의하였다.

2.2.3. 분석방법 표준급여모형을 개발하기 위한 분석은 다섯 단계로 나누어 실시되었다. 첫 번째 단 계는 데이터 탐색 단계로 분석대상자의 독립변수 및 종속변수에 결측치 및 이상치 여부를 확인하였다. 두 번째 단계는 표준급여모형의 1 단계인 시설급여 권고모형 개발 단계이다. 1 단계 모형을 개발하기 위 
Table 2.1. The 69 items included in the algorithms

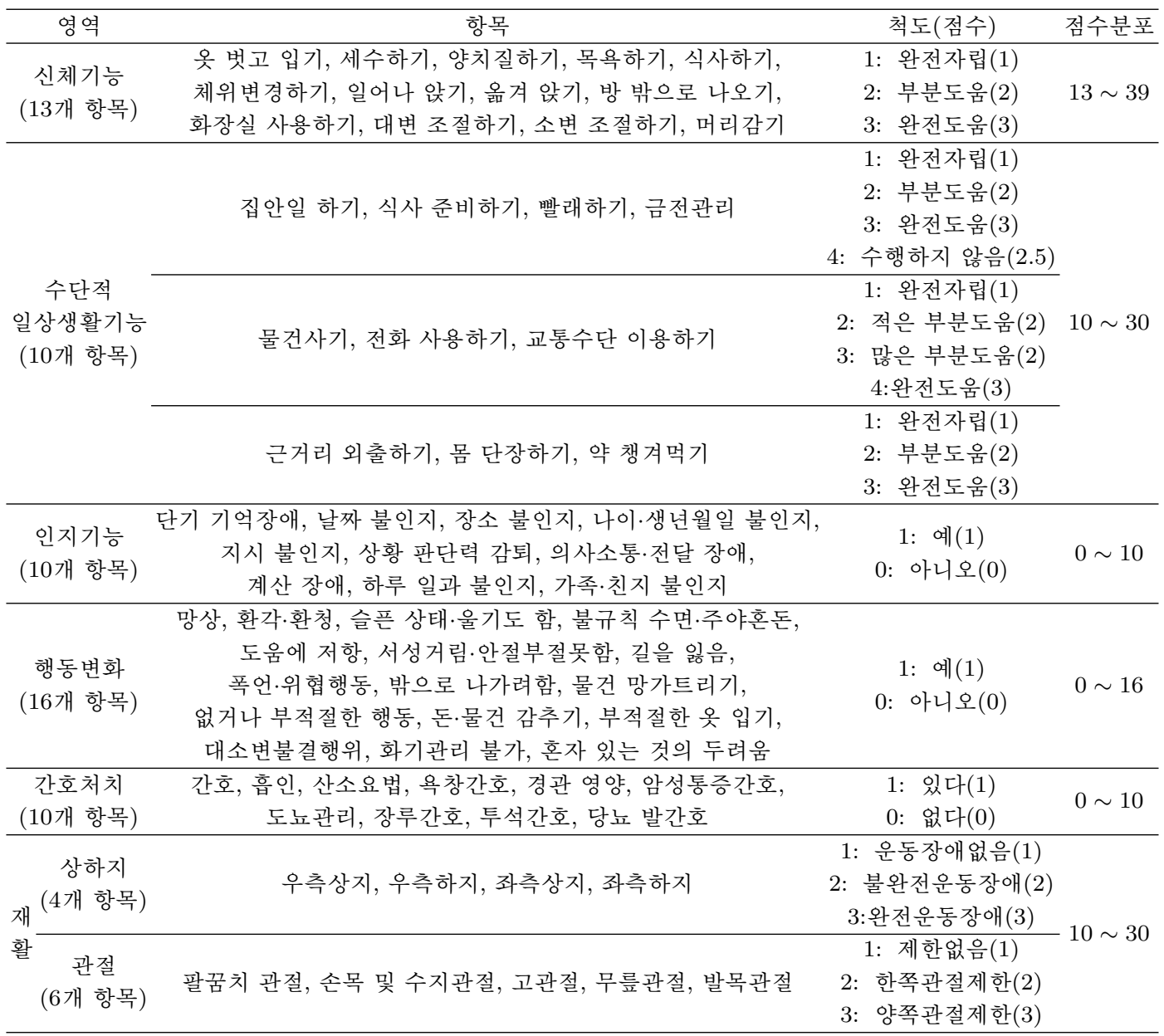

해 먼저 대상자의 인구사회학적 특성과 건강 및 기능 상태에 따라 권고된 시설 및 재가 급여의 분포 를 살펴보았다. 세 번째 단계는 의사결정나무기법을 이용하여 시설급여를 권고하는 모형을 개발하였다. 네 번째 단계는 표준급여모형 1 단계에서 재가급여를 권고 받은 자를 대상으로 재가급여의 세부 급여종 류를 권고하는 표준급여모형 2 단계를 개발하는 단계이다. 방문요양, 방문목욕, 방문간호, 주야간보호 에 대한 각각의 권고모형을 의사결정나무기법을 활용하여 개발하였다. 방문간호의 경우 비권고군의 수 가 권고군의 수보다 약 9 배 정도 높게 나타났다. 이와 같은 자료의 불균형은 모형의 민감도를 떨어뜨 리는 경향이 있어, 분류의 민감도를 높이기 위해 오분류 확률과 더불어 오분류 비용을 고려하는 Elkan (2001)이 소개한 이론을 적용하였다. 이 방법은 방문간호 권고군을 비권고군으로 분류하는 비율을 비 권고군을 권고군으로 분류하는 비율보다 더 높게 정의하여 분석용 자료에서 권고군과 비권고군의 비율 을 변화시키는 것이다. 이에 분류 비용을 $1,3,5,7,9$ 배에 따라 분석을 실시하였으며, 비용을 5 로 주 었을 때 민감도, 특이도, 정확도가 적정한 수준을 나타내어 비용 5 의 결과를 제시하였다. 마지막 단계 는 구축한 모형에 대한 점수화(scoring) 단계로, 모형을 통한 점수화는 2008년 4월 15 일부터 2009년 
7 월 1 일까지 등급판정완료 후 장기요양인정을 받은 254,479 명 중 독립변수에 결측이나 오류자료가 없는 251,583 명을 대상으로 실시하여, 향후 장기요양 급여 종류별로 권고율을 예측하였다.

의사결정나무모형을 통한 표준급여모형 개발 과정은 다음과 같다. 첫째, 데이터 분할단계이다. 최종 분 석대상자를 학습용 자료(training set), 평가용 자료(validation set), 검증용 자료(test set)로 분할하였 다. 표준급여모형 1 단계는 $60: 20: 20$ 으로, 표준급여모형 2 단계는 $70: 20: 10$ 으로 분할하였다. 1 단계에서 재가급여를 권고 받은 대상자에게 세부 재가급여 종류를 권고하는 2 단계에서 방문간호의 권고비율이 $8.2 \%$ 로 다른 재가급여에 비해 너무 낮아 모형의 안정성을 확보하고자 1 단계와는 달리 학습용 자료의 분 할비율 $(70 \%)$ 을 높여 분석을 실시하였다. 둘째, 의사결정나무의 형성 단계로 표준급여모형 1 은 지니지 수(Gini index)를 분리기준으로 사용하는 CART(classification and regression trees) 알고리즘을 통해 형성하였으며, 이지분리를 수행하였다. 그러나 나무 상단에서 선택된 연속형 변수가 아래 가지로 나오 는 일이 빈번하여 나무의 깊이가 깊어지고 해석이 자연스럽지 못하였다. 이에 삼지분리를 수행하여 이 지분리 모형과 비교한 결과 적중률의 큰 차이가 없었고, 해석이 좀 더 자연스러워 삼지분리 결과를 채 택하였다. 표준급여모형 2단계는 카이제곱 통계량을 분리기준으로 사용하는 CHAID(chi-squared automatic interaction detection) 알고리즘을 통해 형성하였으며, 이지분리를 수행하였다. 셋째, 나무는 최대한 크게 적합하고, 오분류율(misclassification rate)을 높게 할 위험(risk)이 있거나 설명할 수 없는 역전현상, 그리고 일반화에 문제가 있는 가지(branch)는 전문가 회의 등을 거쳐 가지치기(pruning)하였 다. 넷째, 모형평가를 위한 통계량으로 정분류율, 민감도, 특이도를 사용하였다.

\section{3. 연구결과}

\section{1. 인구사회학적 특성}

분석대상자의 인구사회학적 특성을 살펴보면, 분석대상자 9,144 명 가운데 남자는 $29.8 \%$, 여자는 $70.2 \%$ 이었고, 연령은 $75-84$ 세가 $41.2 \%$ 로 가장 많았다. 장기요양등급은 1 등급 $18.8 \%, 2$ 등급 $25.7 \%$, 3 등급 $55.5 \%$ 로 3 등급이 가장 많았다. 자격은 일반건강보험 가입자가 $66.9 \%$ 로 가장 많았고, 거주 지역 은 농어촌이 $36.0 \%$ 로 가장 많았으며 그 다음으로는 도농복합 $27.2 \%$, 대도시 $26.2 \%$ 이었다. 거주형태는 자택이 $71.0 \%$, 요양시설이 $28.2 \%$ 이었으며, 자택에 거주하는 6,489 명 가운데 $76.7 \%$ 는 가족과 동거하고 있었다.

\section{2. 표준급여모형 1 단계: 시설급여 권고모형}

시설급여 권고 비율을 살펴보면, 전체 9,144 명 가운데 4,334 명(47.4\%)이 시설급여를 권고 받았고, 그 외 4,810 명 $(52.6 \%)$ 은 재가급여를 권고 받은 것으로 나타났다. 시설급여가 적절한지 재가급여가 적절한 지를 결정하는 표준급여모형 1단계 권고 알고리즘 결과는 Figure 3.1과 같다. 시설급여 권고그룹은 총 20 개로 세분화되었고, 권고그룹을 결정하는 주요 요인은 신체기능영역점수, 행동변화영역점수, 행동변 화 영역의 방 밖으로 나가려함, 폭언·위협적인 행동, 길을 잃음 항목과 재활영역의 무릎관절 장애정도로 나타났다. 신체기능영역점수, 인지기능영역 그리고 행동변화영역 점수가 높을수록 시설급여를 권고 받 을 확률이 높았다. 이와 더불어 방 밖으로 나가려고 하거나 폭언·위협적인 행동, 길을 잃는 등 문제행동 을 일으킬수록 시설급여를 권고 받을 확률이 높았다.

\section{3. 표준급여모형 2 단계: 재가급여 종류별 권고모형}

재가급여 권고군은 4,810 명이었고 이들의 세부 재가급여 종류별 권고 현황을 살펴보면, 방문요양이 


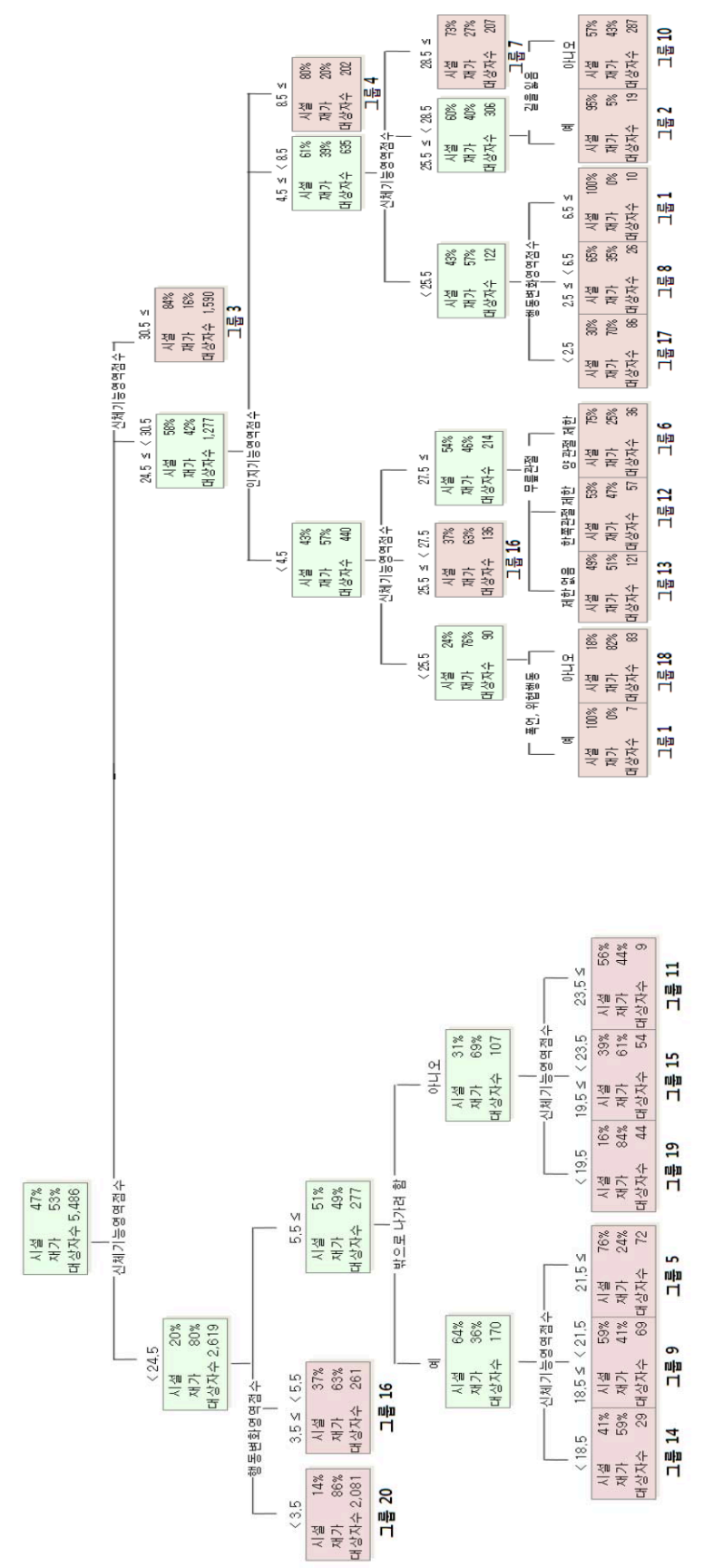

Figure 3.1. Eligibility criteria for In-home care services (Stage II)

$84.2 \%$ 로 가장 높았고, 방문목욕 $57.0 \%$, 주야간보호는 $23.4 \%$ 이었으며, 방문간호는 $8.2 \%$ 에 불과하였 


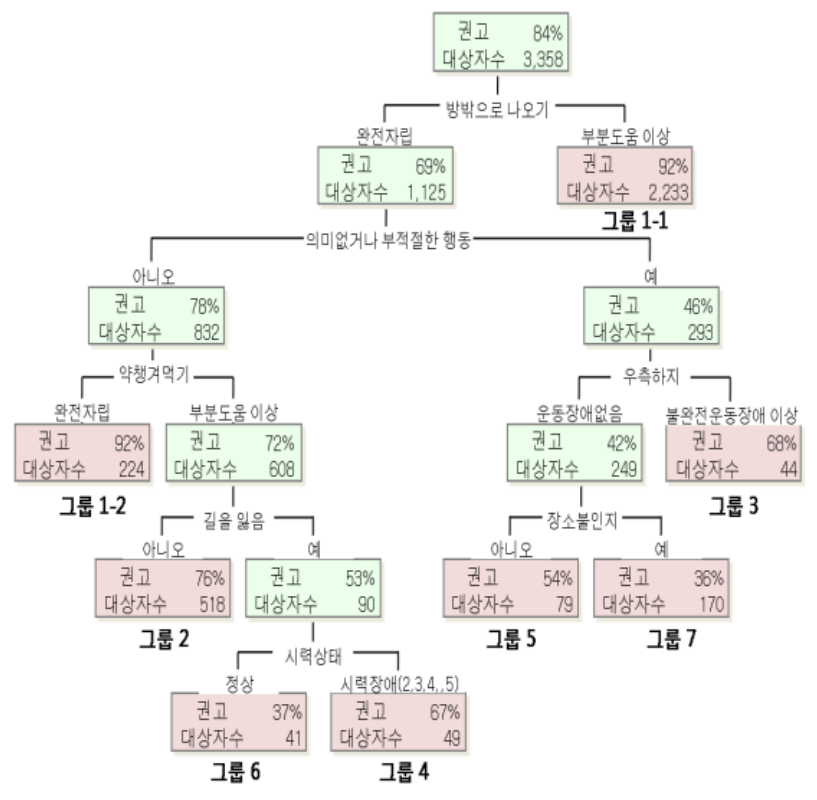

(a) Eligibility criteria for home-visit care

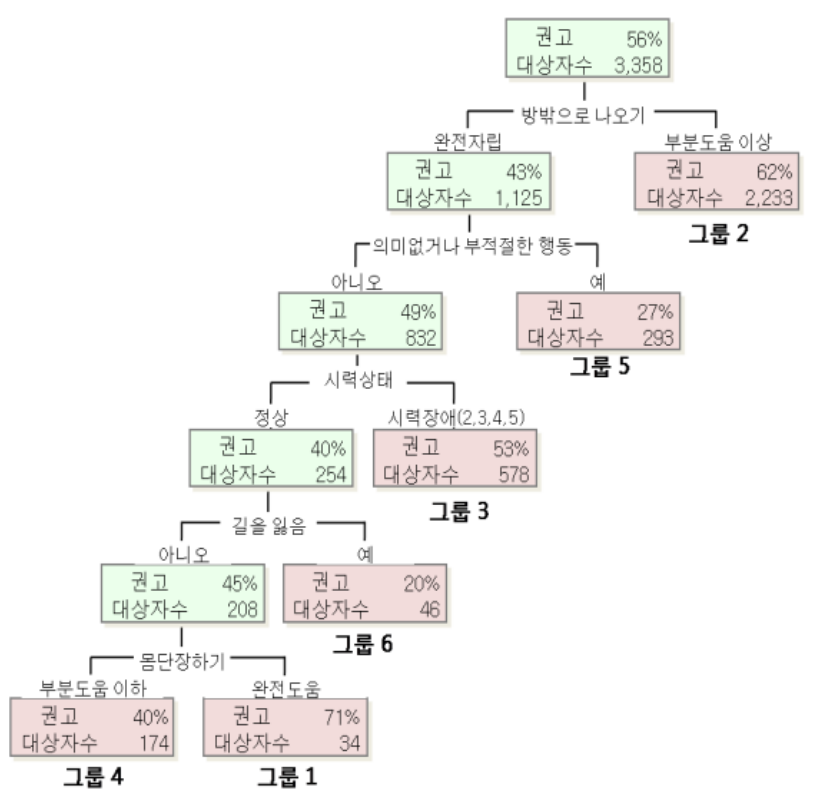

(b) Eligibility criteria for home-visit bathing

Figure 3.2. Eligibility criteria for In-home care services (Stage II)

다.

표준급여모형 2 단계는 표준급여모형 1 단계에서 재가급여를 권고 받은 대상자 중 방문요양, 방문목욕, 


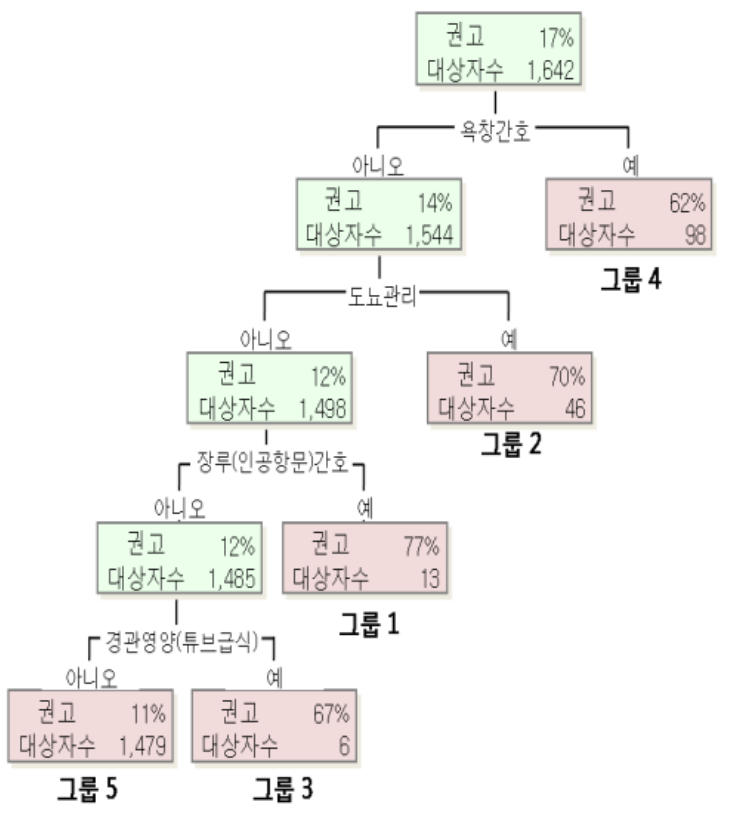

(a) Eligibility criteria for home-visit nursing

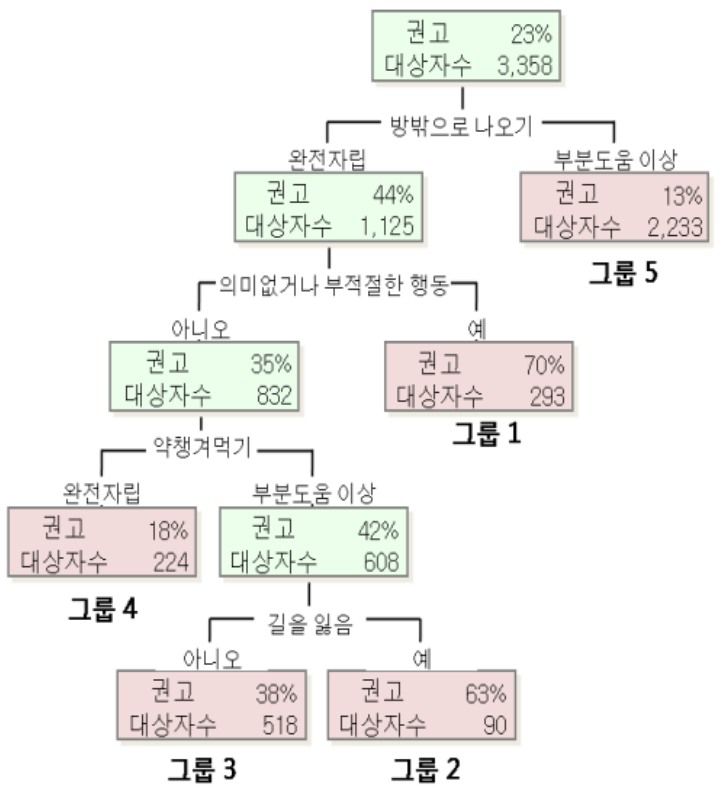

(b) Eligibility criteria for day and night care

Figure 3.3. Eligibility criteria for In-home care services (Stage II) con.

방문간호, 주야간보호를 권고 받을 대상자를 선별하는 단계로, 각 급여 종류별로 구축한 권고모형은 
Table 3.1. Assessments of the algorithms

\begin{tabular}{|c|c|c|c|c|c|c|c|c|}
\hline \multirow{2}{*}{ 단계 } & \multirow{2}{*}{ 모형 } & \multirow{2}{*}{ 임계치 } & \multicolumn{3}{|c|}{ 학습용 자료(\%) } & \multicolumn{3}{|c|}{ 검증용 자료 $(\%)$} \\
\hline & & & 정확도 & 민감도 & 특이도 & 정확도 & 민감도 & 특이도 \\
\hline 1 & 시설 & 50 & 79.22 & 0.78 .33 & 0.80 .21 & 0.7818 & 0.77 .04 & 0.79 .47 \\
\hline \multirow{4}{*}{2} & 방문요양 & 90 & 0.76 .92 & 0.79 .72 & 0.61 .93 & 0.7479 & 0.78 .25 & 0.57 .50 \\
\hline & 방문목욕 & 60 & 0.60 .72 & 0.75 .27 & 0.42 .31 & 0.6375 & 0.76 .87 & 0.47 .17 \\
\hline & 방문간호 & 20 & 0.86 .30 & 0.38 .69 & 0.95 .83 & 0.8511 & 0.31 .43 & 0.94 .50 \\
\hline & 주야간보호 & 20 & 0.77 .01 & 0.58 .20 & 0.82 .77 & 0.7458 & 0.54 .55 & 0.81 .34 \\
\hline
\end{tabular}

Figure 3.2-Figure 3.3과 같다. 방문요양의 경우, 방밖으로 나오기가 부분도움이거나 완전도움인 경우, 또는 방밖으로 나오기가 완전자립이고, 의미 없거나 부적절한 행동을 하지 않고, 약챙겨먹기가 완전자립 인 경우 방문요양을 권고 받을 확률이 높은 것으로 나타났다. 방문목욕은 방밖으로 나오기가 완전자립 이고, 의미 없거나 부적절한 행동을 하지 않고 시력상태가 정상이며, 길을 잃지 않고, 몸단장하기가 완 전도움인 경우 권고 받을 확률이 높았다. 방문간호는 욕창간호가 필요하고, 도뇨관리는 없으며, 장루간 호를 받고 있는 경우 권고 받을 확률이 높았고, 주야간보호는 방밖으로 나오기가 완전자립이고 의미 없 거나 부적절한 행동을 하는 경우였다.

\section{4. 표준급여모형의 타당성 평가}

모형의 타당성을 평가하는 방법으로는 다양한 통계량이 사용될 수 있다. 본 연구에서는 학습용 데이터 와 평가용 데이터 각각에 대해 정분류율과 민감도 그리고 특이도룰 통해 모형의 성능을 평가하였다. 정 분류율과 민감도, 특이도가 높을수록 좋은 모형이지만 실제 어떠한 모형도 세 통계량을 모두 높게 하는 분류 임계치란 존재하지 않는다 (Kang, 1999). 따라서 이 세 통계량 중 어느 하나가 지나치게 크거나 지나치게 작지 않은 임계치를 찾는 것이 바람직하다. 이에 각 모형별로 임계치에 따라 구한 정분류율, 민감도, 특이도를 정분류도표(correct classification charts)에 나타내어 적정 분류 기준 값을 선정하였 다. 표준급여모형에 대해 적정 분류 기준 값에 대한 학습용 데이터와 평가용 데이터의 정분류율, 민감 도, 특이도를 살펴보면 Table 3.1 과 같다. 표준급여모형 1 단계인 시설과 재가급여 분류 모형은 정분류 율 $78,18 \%$, 민감도 $77.04 \%$, 특이도 $79.47 \%$ 로 매우 좋은 성능을 보였다. 표준급여모형 2 단계인 세부 재 가급여 종류별 모형을 살펴보면, 방문요양 권고모형의 경우, 분석 자료의 임계치 90 일 때 정분류율, 민 감도, 특이도가 적정 값을 나타냈고, 이때 평가용 자료의 정분류율은 $74.79 \%$, 민감도 $78.25 \%$, 특이도 $57.50 \%$ 로 좋은 성능을 보였다. 방문목욕은 임계치 60 에서 정분류율 $63.75 \%$, 민감도 $76.87 \%$, 특이도 $47.17 \%$ 로 모두 적정한 수준을 나타내었다. 방문간호의 경우, 임계치 20 에서 정분류율과 특이도는 각각 $85.11 \%$ 과 $94.50 \%$ 로 높게 나타났지만, 민감도는 $31.43 \%$ 로 낮게 나타났다. 주야간보호는 임계치 20 에 서 정분류율 $74.58 \%$, 민감도 $54.55 \%$, 특이도 $81.34 \%$ 로 적정한 수준을 나타내었다.

\section{5. 표준급여모형 시범 적용 결과}

본 연구에서 개발한 표준급여모형을 2009년 4월 15 일부터 2009년 7월 1일까지 등급판정을 완료한 등급 내( $1 \sim 3$ 등급) 판정자 251,583 명에 시범 적용해보았다. 그 결과, 표준급여모형 1 단계를 통해 시설급여 를 권고 받은 대상자는 전체의 $52.5 \%$ 안 132,187 명이었다. 표준급여모형 1 단계에서 재가급여를 권고 받 은 119,396 명을 대상으로 표준급여모형 2 단계인 세부 재가급여 모형별로 급여종류를 추정하였으며, 그 결과 권고율이 방문요양 $73.8 \%$, 방문목욕 $69.2 \%$, 방문간호 $3.9 \%$, 주야간보호 $26.2 \%$ 다. 재가급여 조합 별로 살펴보면 방문요양과 방문목욕을 함께 권고 받은 대상자의 재가급여 권고자의 $65.1 \%$ 로 가장 많았 
Table 3.2. Distribution of specific services after applying the model

\begin{tabular}{|c|c|c|c|}
\hline \multirow{2}{*}{ 단계 } & 구분 & $N$ & $\%$ \\
\hline & 전체 & 251,583 & \\
\hline \multirow{2}{*}{ 표준급여모형 1} & 시설 & 132,187 & 52.5 \\
\hline & 재가 & 119,396 & 47.5 \\
\hline \multirow{4}{*}{ 표준급여모형 $2^{1)}$} & 방문요양 & 88,138 & 73.8 \\
\hline & 방문목욕 & 82,650 & 69.2 \\
\hline & 주야간보호 & 31,258 & 26.2 \\
\hline & 방문간호 & 4,665 & 3.9 \\
\hline \multirow{8}{*}{ 재가급여 조합 2$)$} & 조합1 : 방문요양 + 방문목욕 + 방문간호 + 주야간보호 & 77,721 & 65.1 \\
\hline & 조합2: 주야간보호 & 29,572 & 24.8 \\
\hline & 조합3 : 방문요양 & 6,362 & 5.3 \\
\hline & 조합4 : 방문요양 + 방문목욕 + 방문간호 & 3,819 & 3.2 \\
\hline & 조합5 : 방문목욕 $+\quad$ 주야간보호 & 1,076 & 0.9 \\
\hline & 조합6 : 방문간호 + 주야간보호 & 576 & 0.5 \\
\hline & 조합7 : 방문요양 $+\quad$ 방문간호 & 236 & 0.2 \\
\hline & 조합8 : 방문목욕 + 방문간호 + 주야간보호 & 34 & 0.0 \\
\hline
\end{tabular}

1) 표준급여모형 1단계에서 재가급여를 권고 받은 119,396 명 대상

2) 표준급여모형 2 단계에서 권고 받은 재가급여의 조합

고, 주야간보호의 권고비율이 $24.8 \%$ 로 그 다음을 차지하였다. 나머지 $10.1 \%$ 는 방문요양이 $5.3 \%$, 방문 요양, 방문목욕, 방문간호를 같이 권고 받은 사람이 $3.2 \%$ 를 차지하였다(Table 3.2 ).

\section{4. 결론}

본 연구는 노인장기요양보험제도 도입 이후 지속적으로 제기되어 온 표준이용계획서 작성자 간 전공과 개인의 성향에 따른 급여계획의 편차발생 문제, 표준이용계획에 수급자의 기능 및 건강상태 반영이 미흡 하다는 문제를 통계학적 모델링 기법을 적용하여 해소하고자 이루어졌다. 본 연구에서 제안한 표준급여 모형은 $\operatorname{Han}$ 등 (2009)이 개발한 모형이 갖고 있는 한계점인 수급자의 건강 및 기능 상태에 따른 적정 급여계획을 담고 있는 자료의 부적정성과 재가급여 세부 종류별 알고리즘을 도출하지 못한 점을 개선하 고자 하였다는 데에 그 의의가 있다.

표준급여모형은 다양한 데이터마이닝 기법 중 의사결정나무기법만을 활용하였다. 의사결정나무기법은 배깅이나 부스팅과 같은 앙상블 모형에 비해 예측력이 떨어지는 단점이 있으나, 표준급여모형이 실제 표 준이용계획서를 작성하는 225 개 장기요양운영센터 현장에 활용되어야 한다는 점을 고려하여 분류나 예 측의 과정을 제시하여 모형의 결과를 다른 모형보다 이해하기 쉬운 의사결정나무기법을 활용하였다.

본 연구는 수급자의 건강 및 기능 상태에 맞는 최적의 급여계획을 도출하는 표준급여모형을 개발하였고, 이를 공단의 장기요양운영센터 직원들이 표준이용계획서 작성 시에 실제로 활용하고 있다는 데에 의의 가 있지만, 일부 권고모형에서 특이도와 민감도가 낮게 나타난 한계점을 갖는다. 방문목욕 권고모형의 경우, 다른 모형에 비해 특이도가 낮았고(47.14\%), 방문간호는 민감도가 낮았다(38.69\%). 방문목욕 모 형의 낮은 특이도는 방문목욕이 필요하지 않은 사람에게도 이를 권고한다는 것을 의미하며, 이에 반해, 방문간호의 경우는 방문간호가 필요한 대상자에게 방문간호를 권고하지 못하는 것을 의미한다. 방문간 호의 경우 권고군의 비율이 너무 낮아 민감도가 떨어질 것을 우려하여 분석과정에서 Elkan (2001)이 소 개한 비용이론을 적용하였으나 이와 같은 문제점을 극복하지 못한 것으로 보인다. 이는 본 연구자료 생 
산을 위해 참여한 훈련된 조사자들이 다른 급여에 비해 방문목욕과 방문간호의 필요 여부에 대한 정확한 판단 기준을 갖고 있지 않아서 발생한 결과라고 해석할 수 있다. 따라서 향후 표준급여모형의 타당도를 높이기 위해서는 방문목욕과 방문간호의 권고여부 판단 기준에 대한 지침개발과 지속적인 교육과 훈련 을 제공할 필요가 있다.

본 연구에서 제안한 표준급여모형은 표준이용계획서 작성 전문가가 작성한 데이터를 바탕으로 통계적 알고리즘을 통해 개발된 것으로 장기요양인정조사 결과를 입력하면 수급자의 건강 및 기능 상태를 고 려한 급여 종류가 자동으로 도출되도록 전산프로그램으로 개발되었다. 공단의 장기요양운영센터 직원 은 이를 토대로 수급자와 가족의 주거형태나 희망급여, 지역사회 자원현황 등을 고려하여 최종적으로 수 급자에게 필요한 적정 급여계획을 수립하게 된다. 이는 작성자마다 급여계획 수립시 중점을 두는 사항, 즉, 수급자의 기능, 주거환경, 또는 가족의 희망 등을 달리함에 따라 발생할 수 있는 급여계획의 차이를 통계모형을 통해 일부 해소할 수 있게 한 것이다. 이와 같은 관점에서 통계적 기법을 활용한 표준급여모 형의 개발은 표준이용계획서 작성에 객관성과 과학성을 확보할 수 있게 하고, 이용지원 업무의 효율성도 향상시킬 것으로 기대할 수 있다. 향후 표준급여모형 도입에 따른 표준이용계획서 작성의 효율성, 객관 성 확보 등에 대해 평가하고, 모형의 정확성을 높이며 의사결정나무기법의 단점을 보완하기 위한 다양한 데이터마이닝 기법을 적용하는 연구가 필요할 것으로 보인다.

\section{References}

Commonwealth of Australia (2006). Aged care assessment and approval guidelines.

Commonwealth of Australia (2007). Aged care client record user guide.

Elkan, C. (2001). The foundations of cost-sensitive learning, In proceedings of the seventeenth international joint conference on artificial intelligence (IJCAI'01), 973-978.

Fries, B. E., Shugarman, L. R., Morris, J. N., Simon, S. E. and James, M. (2002). A Screening system for Michiga's home- and community-based long-term care programs, The Gerontologist, 42, 462-474.

Han, E. J., Lee, J. S., Kim, D. G. and Kang, I. M.(2009). A recommending system for care plan(Res-CP) in long-term care insurance system, The Korean Journal of Applied Statistics, 22, 1229-1237.

Hyun, K. R. and Lee, S. M.(2012). Effects on the functional status changes of LTC(Long-Term-Care) services, The Korean Gerontological Society, 32, 593-609.

Hirdes, J. P., Poss, J. W. and Curtin-Telegdi, N. (2008). The method for assigning priority levels(MAPLe): A new decision-support system for allocating home care resources, BMC Medicine, 6.

Jegal, H. S. (2011). The strategies for improving quality of care in long-term care insurance service: The necessity of integrated health and welfare system for old people and care management, Public Policy Institute for People.

Kang, H. C., Han, S. T., Choi J. H. (1999). Data mining using SAS Enterprise Miner - The method and application, Freedom Academy Press, Seoul.

Lee, Y. K., Jung, K. H., Sunwoo, D., Kim, J. S. and Kim, C. W. et al. (2013). Reform of LTC disability determination system and the development of a demential management model(2013-2-0012), Korea Institute for Health and Social Affairs, Ministry of Health and Welfare, Seoul.

Lee, T. H., Ko, Y. K., Kim, B. N., Kim, H. C., Lee, I. S., Jung, S. H., Jo, E. H., Kim, C. W., Jung, S. C., Lee, E. J., Kwon, H. B., Park, N. U. and Jeon, B. H. (2011). Analysis of the achievements of the national long-term care insurance - Clinical outcomes and the development of quality indicators(series no.3), Korea Institute of Public Finance, Seoul.

Lee, J. S., Han, E. J., Kwon, J. H. and Kang, I. O. (2008). The correlation between standard long-term care plan and long-term care utilization under LTC insurance system(2008-33), National Health Insurance Corporation, Seoul.

Matsuda, S. and Yamamoto, M. (2001). Long-term care insurance and integrated care for the aged in Japan, International Journal of Integrated Care, 1, 1-11.

National Health Insurance Corporation (2013). 2013 Manuals for working on long-term care insurance, Na- 
tional Health Insurance Corporation, Seoul.

OECD (2011). Help wanted? Providing and paying for long-term care.

Seok, J. E. (2006). Elderly longterm care insurance and service delivery system: The institutionalization of care management, Korean Academy of Social Welfare, 143-151.

Sunwoo, D., Kim, C. W., Choi, J. S., Choi, H. J., Yeon, B. K. and Won, C. W. (2007). Evaluation study on the second pilot project of long-term care insurance, Ministry of Health and Welfare, Korea Institute for Health and Social Affairs, Seoul. 


\title{
의사결정나무기법을 활용한 노인장기요양보험 표준급여모형 개발
}

\author{
한은정 $^{a} \cdot$ 이정석 $^{a} \cdot$ 김동건 $^{b} \cdot$ 권진희 $^{a, 1}$ \\ ${ }^{a}$ 국민건강보험공단 건강보험정책연구원, ${ }^{b}$ 동덕여자대학교 정보통계학과 \\ (2014년 5월 9일 접수, 2014년 7월 10일 수정, 2014년 9월 15일 채택)
}

요 약

우리나라 노인장기요양보험에서는 수급자가 월 한도액 범위 내에서 필요한 서비스를 비용-효율적으로 이용할 수 있 도록 지원하고자 표준장기요양이용계획서를 작성하여 제공하고 있다. 본 연구는 표준장기요양이용계획서의 객관성 확보와 업무 효율성 제고를 위하여 의사결정나무기법을 이용해 수급자의 건강 및 기능 상태에 맞는 최적의 급여계획 을 도출하는 표준급여모형을 개발하였다. 타당도 높은 모형 개발을 위하여 국민건강보험공단의 전국 220 개 장기요 양운영센터로부터 장기요양인정조사와 표준장기요양이용계획서 작성 경험이 풍부한 직원(본 연구에서는 ‘훈련된 조 사자'라고 함)을 추천받아 자료수집의 내용과 방법에 대해 교육을 실시하였고, 이들이 수급자의 건강 및 기능 상태를 평가하고 작성한 수급자 개인별 맞춤형 급여계획을 자료 분석에 활용하였다. 표준급여모형은 1 단계로 시설 또는 재 가 급여 권고 여부를 결정하는 모형을, 2 단계로 재가급여를 권고했을 경우의 재가급여 세부 종류별 권고 여부를 결 정하는 모형을 개발하였다. 본 연구에서 개발된 표준급여모형은 전산프로그램화 되어 국민건강보험공단 직원이 수 급자에게 제공할 표준장기요양이용계획을 수립하는 과정에 실제로 활용되고 있어 표준장기요양이용계획서의 객관성 확보와 업무 효율화가 기대된다.

주요용어: 노인장기요양보험, 표준장기요양이용계획서, 의사결정나무.

1교신저자: (121-710) 서울특별시 마포구 마포대로 130 , 국민건강보험공단 건강보험정책연구원.

E-mail: kwonjh@nhis.or.kr/tmigkjh@naver.com 